MAY

2017

WHAT WE KNOW AND DON'T KNOW ABOUT SUICIDE PAGE 8
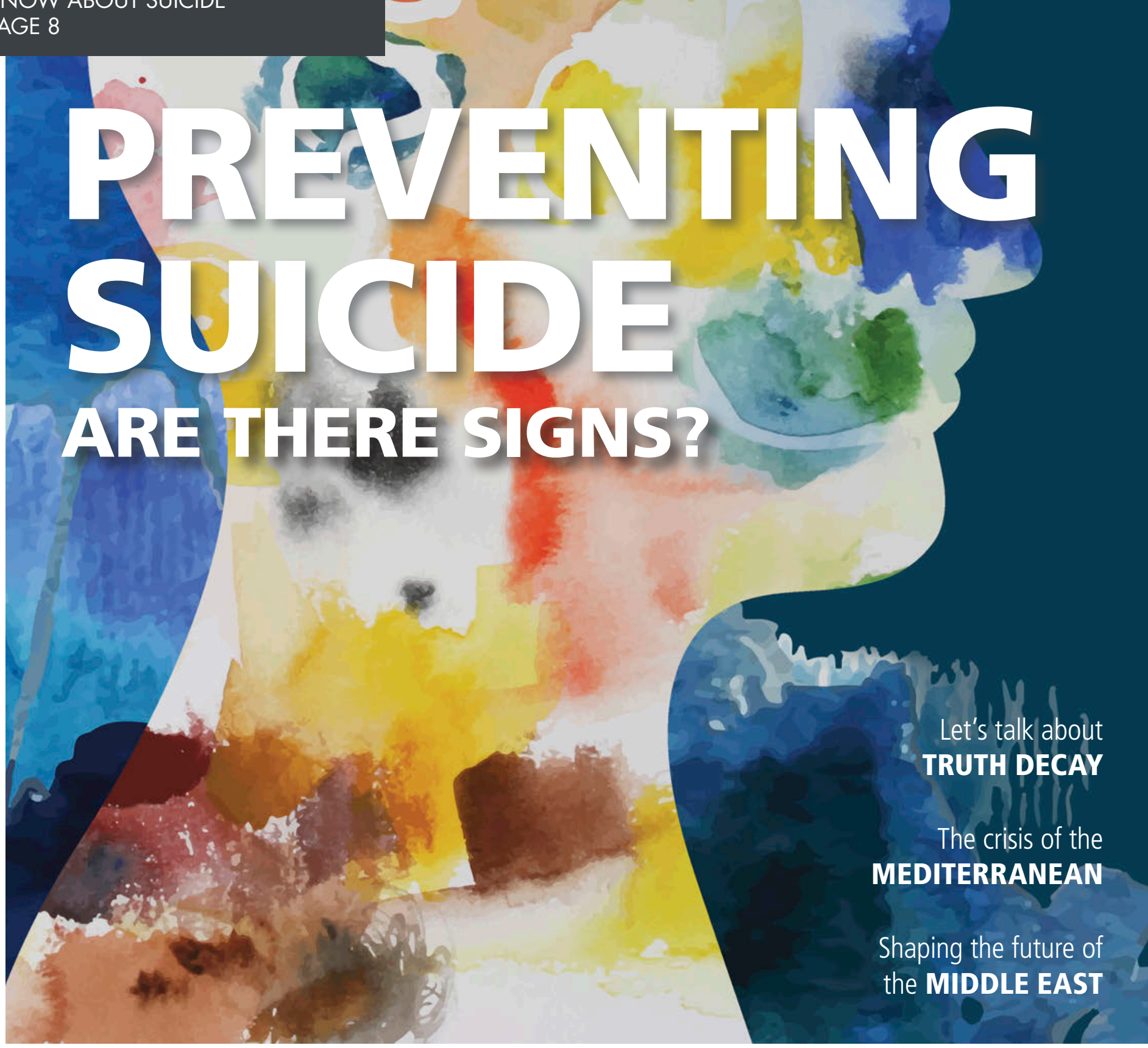

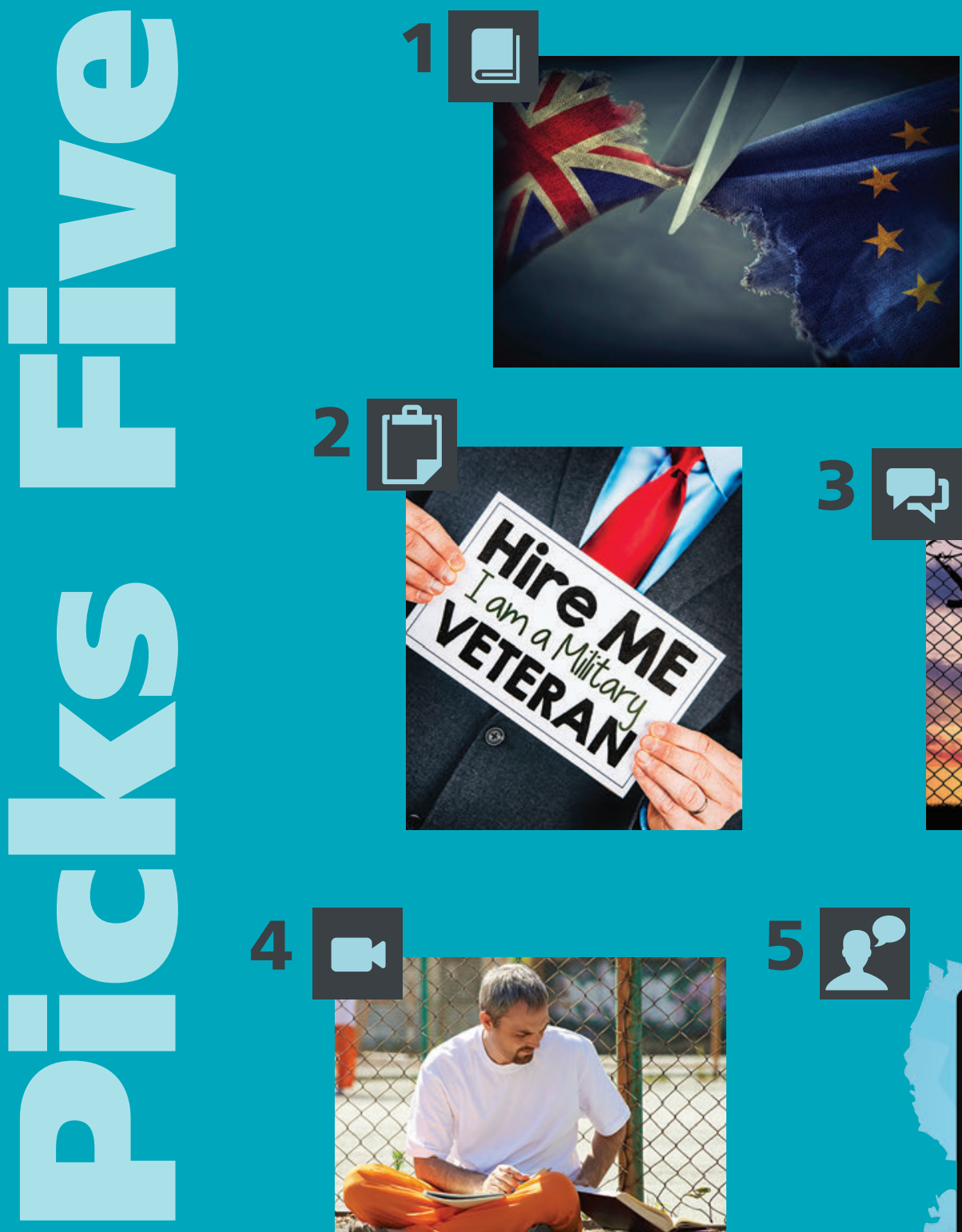

¿ BOOK

[?] TOOL

BLOG

c VIDEO

$\Omega$ TESTIMONY
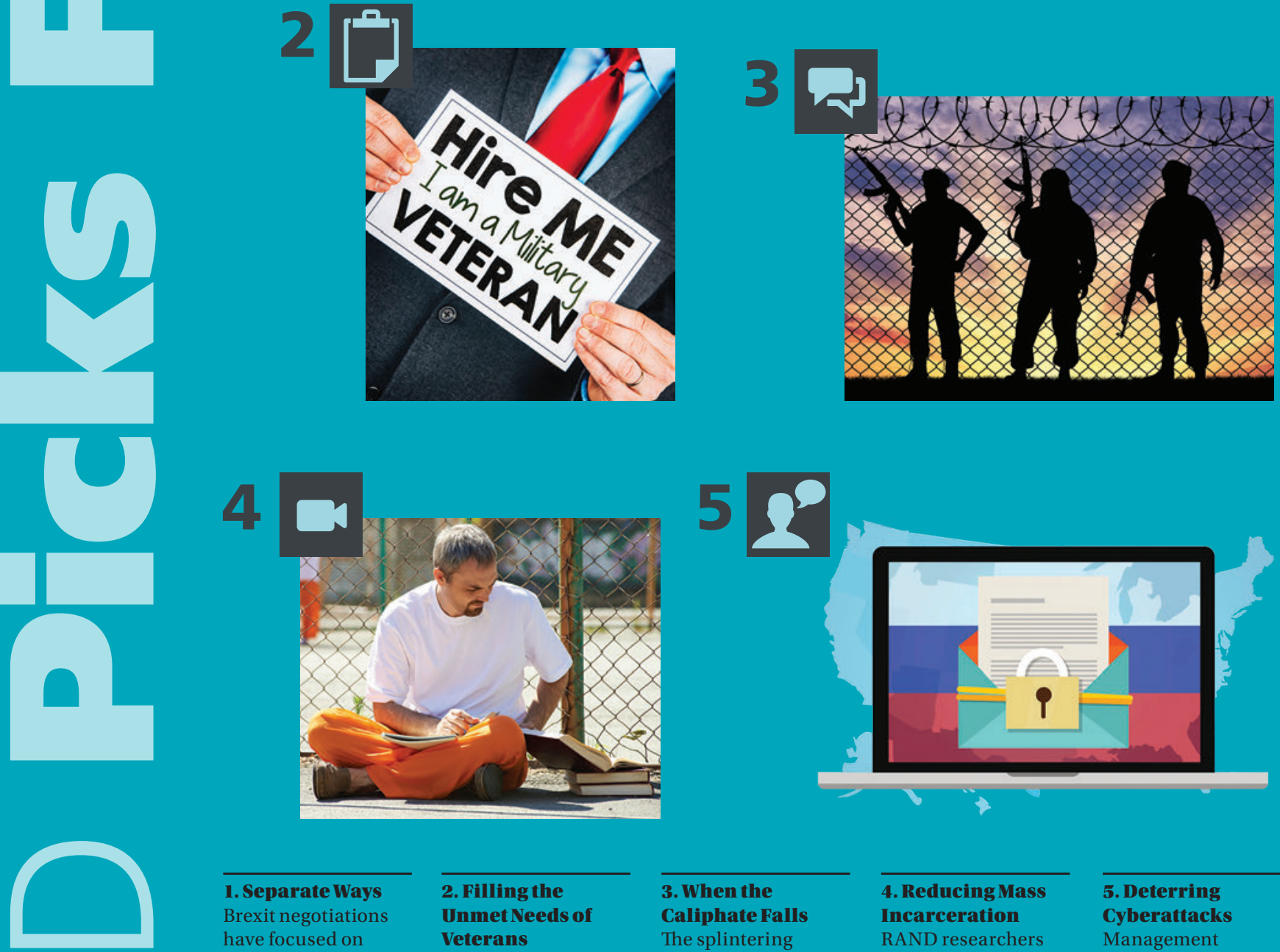

1. Separate Ways Brexit negotiations have focused on trade, sovereignty, and immigration. But the UK's decision to leave the EU also raises important defense and security questions.

MORE AT www.rand.org/t/RR1786

\section{Filling the} Unmet Needs of Veterans

This interactive tool features data and information about state-level programs collected in support of a study of the needs and well-being of Massachusetts

veterans and

National Guard/ reserve members.

MORE AT www.rand.org/t/TL228
3. When the Caliphate Falls The splintering of ISIS should be welcomed. But splinter groups can have different objectives and operating procedures from those of the parent organization, and the world will need to adjust its counterterrorism strategies to address these differences.

MOREAT www.rand.org/ b170306isis

\section{Reducing Mass} Incarceration

RAND researchers have been exploring the effects of correctional education on recidivism and postrelease employment outcomes, and its cost-effectiveness. The results are encouraging.

MORE AT www.rand.org/v161212

\section{Deterring} Cyberattacks Management scientist Martin C. Libicki, in testimony presented before the House Armed Services Committee in March 2017, says that it takes more than offensive capability to have an effective cyberdeterrence posture.

MORE AT www.rand.org/t/CT465 
RANDREVIEW

8

Is suicide preventable? What if we're looking for solutions in the wrong place?

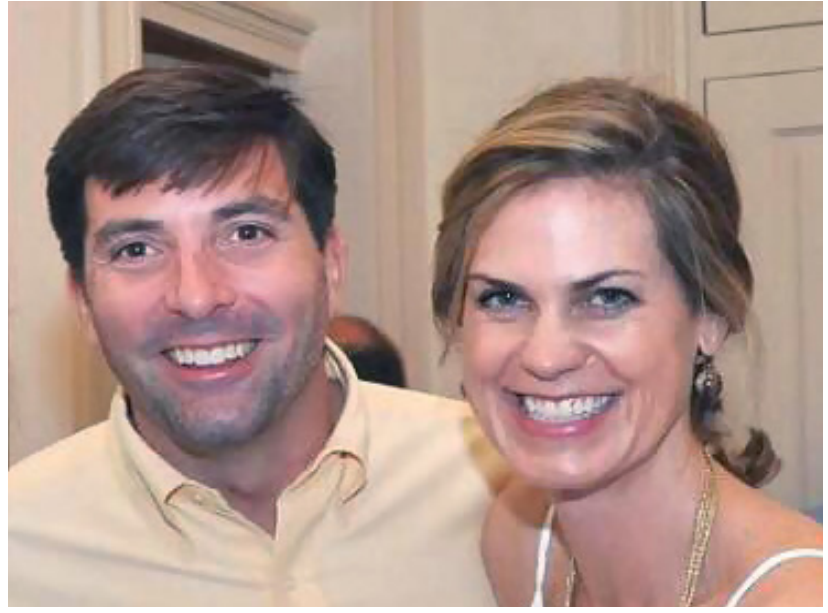

Wilkins Kearney (left) died by suicide in 2016. He was 41, recently married, andaccording to friends and family - never displayed any warning signs in the days before his death. RAND research has found that the warning signs that have become a focus of public-service campaigns might not be reliable. Greater focus on mentalhealth services and family support might be more effective.
4

Voices The corrosive danger of truth decay

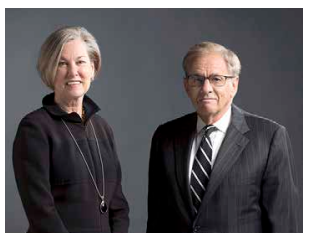

Eye on the Mediterranean The region faces historic challenges to its safety and security. The migrant crisis is just the start

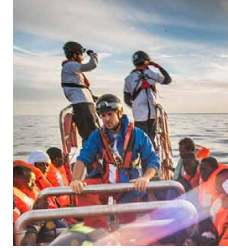

20 Giving Taking a stand against misinformation

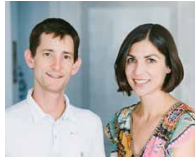
are shaping the Middle East

\section{1 at RANDom}

RAND, "demon dialing," and the movie that shook a president

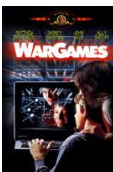

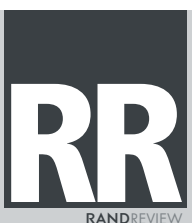

MAY-JUNE 2017

OBJECTIVE ANALYSIS.

EFFECTIVE SOLUTIONS.

WWW.RAND.ORG

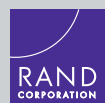

RAND BOARD OF TRUSTEES

KAREN ELLIOTT HOUSE (chair),

MICHAEL LYNTON (vice chair),

BARBARA BARRETT, CARL BILDT,

RICHARD J. DANZIG, KENNETH R.

FEINBERG, MALCOLM GLADWELL,

MICHAEL GOULD, PEDRO JOSÉ

GREER, JR., CHUCK HAGEL, BONNIE

G. HILL, JOEL Z. HYATT, LIONEL C.

JOHNSON, PAUL G. KAMINSKI, ANN

MCLAUGHLIN KOROLOGOS, PHILIP

LADER, JAMES B. LOVELACE, PETER

LOWY, SOLEDAD O'BRIEN, GERALD

PARSKY, MARY E. PETERS, DAVID L.

PORGES, DONALD B. RICE, MICHAEL

D. RICH, HECTOR RUIZ, LEONARD D.

SCHAEFFER

TRUSTEES EMERITI

HAROLD BROWN, FRANK C. CARLUCC
EDITORIAL

Steve Baeck, Manager

Corporate Communications

DESIGN

Dori Gordon Walker

PRODUCTION

Todd Duft

CIRCULATION

Nora Pasco
LETTERS

Send letters to RAND REVIEW, 1776 Main Street, P.0. Box 2138, Santa Monica, CA 90407-2138, or e-mail letters@rand.org

PERMISSIONS

For information about using materia published in RAND REVIEW, visit www. rand.org/publications/permissions/

COPIES

For hard copies of RAND REVIEW, call (877) 584-8642 (toll free) or (310) 4517002 (outside the United States); send a fax to (412) 802-4981; or e-mail order@rand.org
REPORTS

RAND reports are available on rand.org for free PDF download or can be purchased as hard copies. RAND e-books are also available fo Amazon's Kindle, Apple's iBooks, and for most other popular e-book platforms.

SEARCH

RAND documents can be searched by author, title, and category at www.rand.org/pubs

C Copyright 2017 RAND Corporation RAND is a registered trademark. 


\section{Research}
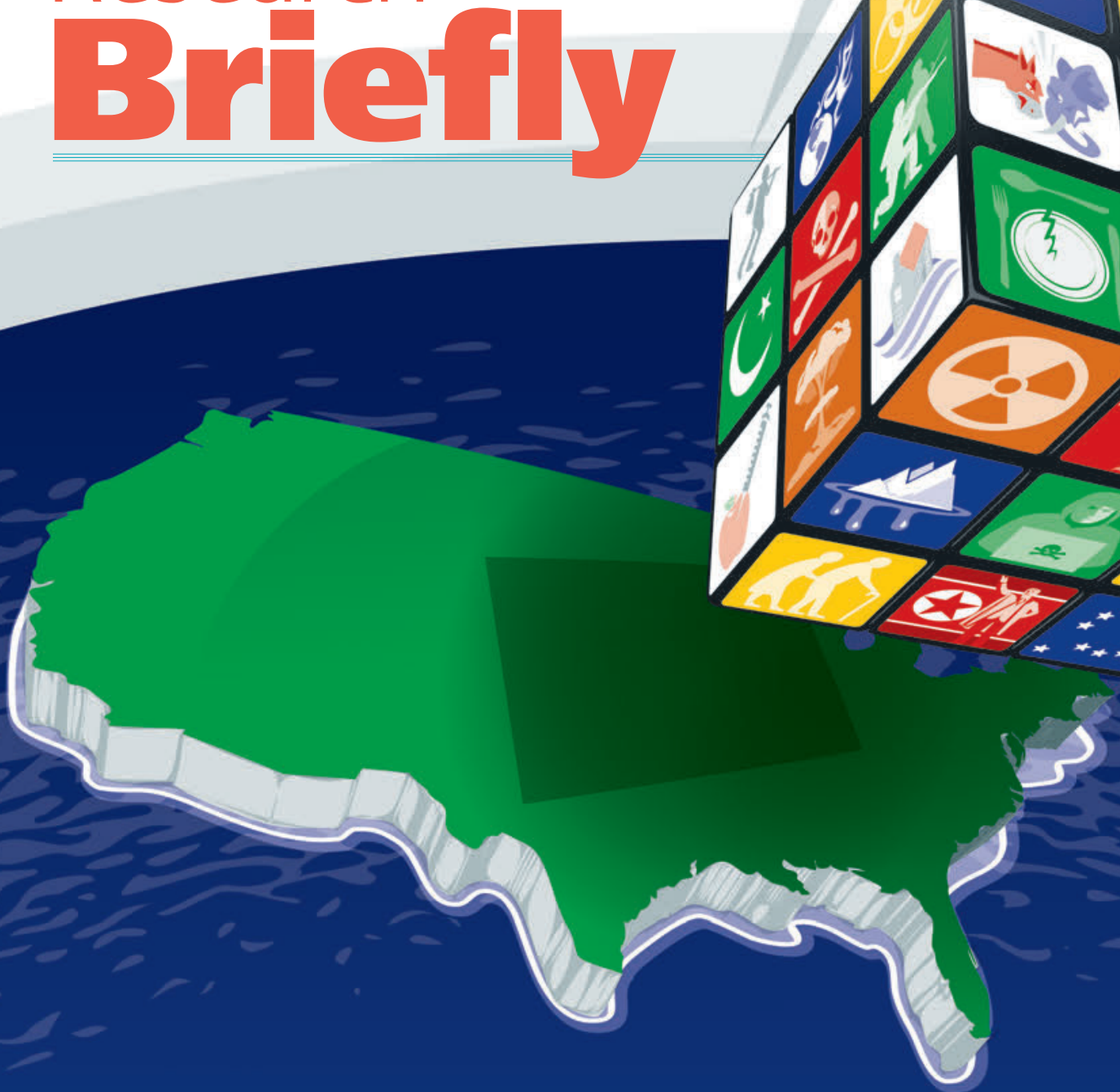

\section{In Pursuit of Security and Opportunity}

American politics have become so bitterly dysfunctional that they now pose the greatest threat to effective U.S. leadership in the world, RAND experts warn.

The international order that the United States and its allies built from the wreckage of World War II is fraying. The world has entered a new and turbulent age, the experts concluded: "Threats that once came from 'somewhere' can now come from 'anywhere."'

America faces a "Rubik's Cube" of international risk—from Russia, China, and the Islamic State to emerging diseases, nuclear proliferation, and climate change. It is still better positioned than any of its rivals to address those threats, the experts wrote, but first it must break the political deadlock of Washington.

The nation needs a strategic vision, a consensus on the role it wants to play in world affairs. It can choose one of three plausible paths: turn its attention inward and prioritize domestic renewal over international engagement; reaffirm its role as the sponsor-and chief economic beneficiary—of world order; or realign its domestic and foreign policies to focus first and foremost on becoming more competitive in the world economy.

Each of these paths has costs and benefits, and a real answer to America's problems will likely have to borrow from them all. But they all share the same first step: Leaders in Washington need to put aside their partisan differences and reach some agreement over when and where America engages in the world, and how it plans to pay for that. Anything less, the experts warned, will only magnify the risks we already face.

\section{MORE AT}

wWW.rand.org/t/RR1631

Support for this RAND Venture was provided, in part, by the generosity of RAND's donors. Special appreciation goes to the Hauser Foundation for its generous gift in support of the "Strategic Rethink" series and to Rita Hauser for encouraging RAND to undertake it. 


\begin{abstract}
12,000 Futures
The Colorado River supplies water to more than 30 million people. It supports billions of dollars in economic activity and irrigates 15 percent of all U.S. crops. Yet growing demand and a changing climate have muddied its future.

That poses real challenges for water managers and planners trying to preserve the Colorado as a lifeline for the American southwest. To cut through the uncertainty, RAND researchers recently analyzed not just one possible future, but 12,000 of them. And they did it over lunch.

Water managers, who have been working for years to ensure the river will continue to meet its diverse needs, first turned to RAND for assistance in 2012. RAND's approach put a twist on the usual forecasting methods. Rather than try to predict the future and then plan for it, they developed their planning options first and then tested how well they would work against many different scenarios.
\end{abstract}

That kind of modeling requires some serious computer power; the 2012 study took an entire summer of analysis. In an unprecedented partnership, RAND researchers joined forces with the Lawrence Livermore National Laboratory to

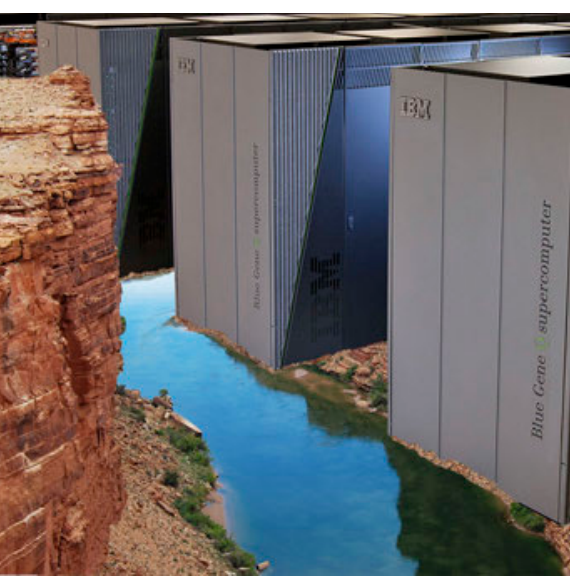
demonstrate how highspeed supercomputers could revolutionize such planning.

They asked water managers in the Colorado basin to develop five new water-management strategies. They then used a Lawrence Livermore supercomputer to evaluate those strategies against 12,000 possible future scenarios, a total of 60,000 simulations. The same analysis that demanded months of computing a few years ago took just 45 minutes with the supercomputer-just enough time for the human participants to grab some sandwiches.

The results underscored the need for conservation, groundand seawater desalination, and wastewater reuse to keep the Colorado healthy. But the project also demonstrated the potential for supercomputers to improve and advance public-policy decisionmaking-especially amid the deep uncertainties of a changing world.

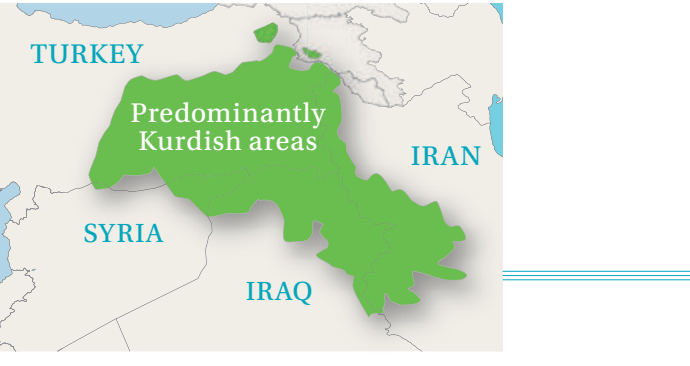

Implications of an Independent Kurdistan

The Kurds have become the largest diaspora community in the world, a nation of some 30 million people without a country of their own. What they have instead is a mountainous patch of northern Iraq where they run their own schools, patrol their own borders, and dream of an independent Kurdistan.

A recent RAND report analyzed what it would mean for regional stability if the Kurds ever did break away from Iraq and form a new country. It focused especially on how the three regional powers that share the neighborhood-Iraq, Iran, and Turkey—might respond.

All three have historically opposed Kurdish independence, often violently. Turkey and Iran have their own Kurdish populations and have been wary of any independence movement spreading.

But both have established investment and trade ties with the Kurds in northern Iraq, ever since a no-fly zone established their enclave in 1991. Turkey, especially, might prefer to have a stable Kurdish state on its southern border, rather than rely on Baghdad to keep the peace there.

In fact, Baghdad might be the only regional capital that would still fight to keep the Kurds as part of Iraq. But it also has to worry about the Islamic State, a financial crisis, and ethnic and political divisions that have split the government. It might not have the wherewithal to stop them from leaving.

Researchers concluded that a negotiated split of the Kurds from Iraq could be done peacefully, with the conditional approval of Iran and Turkey. But they cautioned that a sudden, unilateral declaration of Kurdish independence could inflame those old hostilities and further destabilize the region.

MORE AT

www.rand.org/t/RR1452

Funding for this RAND Venture was provided, in part, by donors and by the independent research and development provisions of RAND's contracts for the operation of its U.S. Department of Defense federally funded research and development centers. 


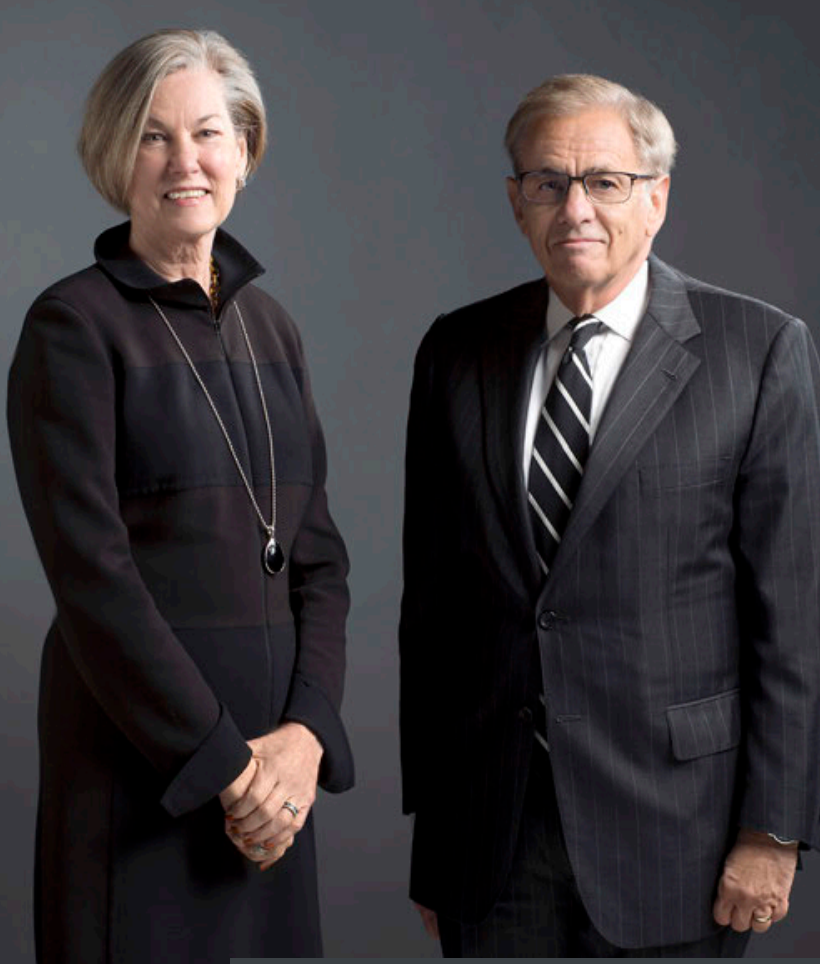

BY

Karen Elliott House and Michael D. Rich

Karen Elliott House chairs the RAND Board of Trustees. She is the former publisher of The Wall Street Journal and former senior vice president of Dow Jones and Company, Inc. Michael D. Rich is RAND's president and CEO. He began his career at RAND in 1975 as a summer intern and has served in a leadership role for more than three decades.

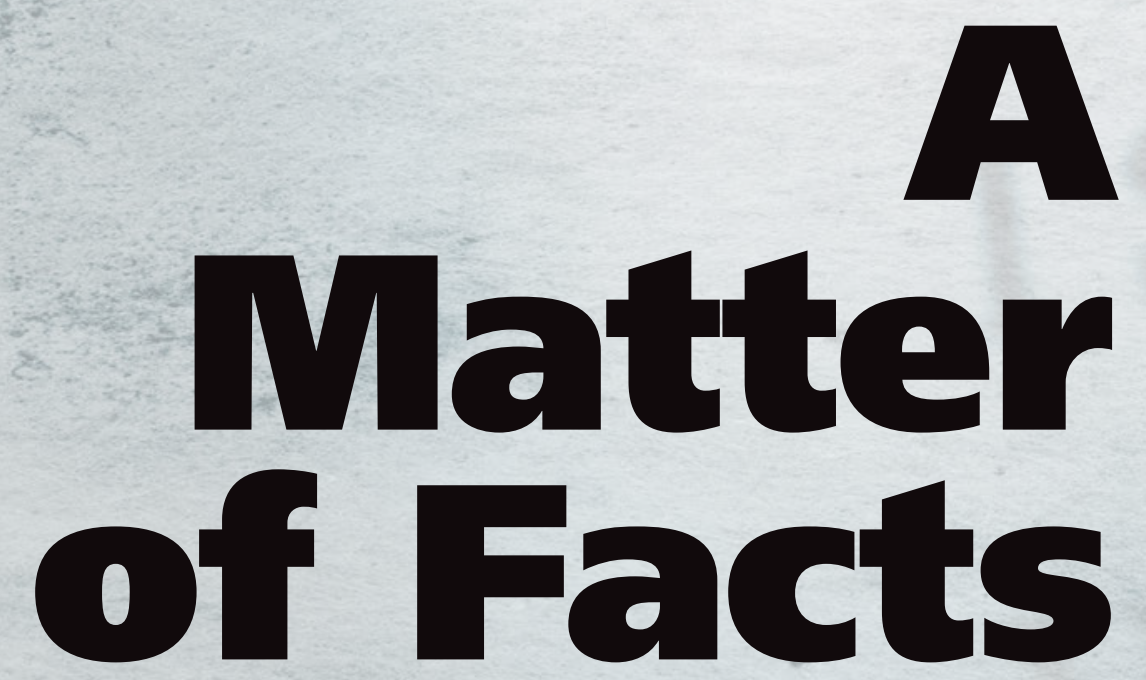

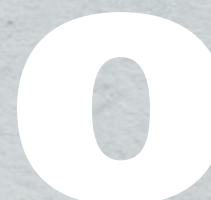

n March 14, 1988, the United States Senate accomplished something that seems extraordinary in hindsight: It voted unanimously to ratify an international treaty to ban the use of chemicals that could harm the Earth's ozone layer.

It was a triumph of bipartisanship, but it was also a triumph of research, of facts over falsehoods. For years, scientists and experts, including many at the RAND 


\section{Locations}

RAND's North American locations include Santa Monica, California, the home of its headquarters campus and the Pardee RAND Graduate School; Arlington, Virginia; Pittsburgh, Pennsylvania; and Boston, Massachusetts. The RAND Gulf States Policy Institute is in New Orleans, Louisiana. Our newest office is in the San Francisco Bay Area. RAND Europe is located in Cambridge, United Kingdom, and Brussels, Belgium. RAND Australia is located in Canberra.
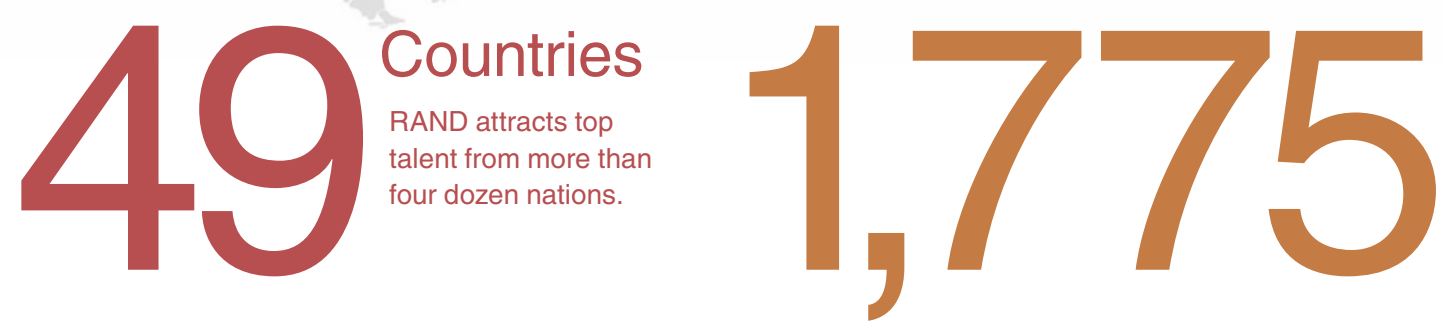

\section{Staff}

RAND attracts top talent from more than four dozen nations.

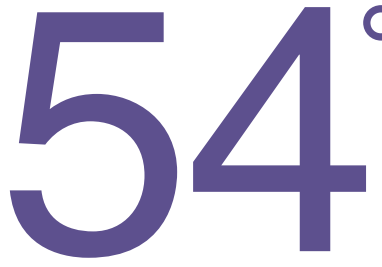

$\%$ Hold Doctorates

Well over half our research staff of $\sim 1,050$ hold one or more doctorates in an array of disciplines.

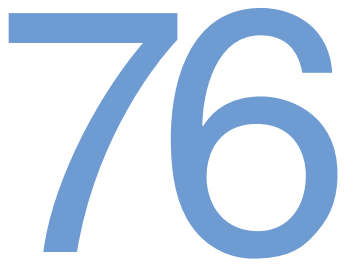

Languages

Many of our staff are multilingual. Languages spoken include Arabic, Chinese, Farsi, French, German, Japanese, Korean, Russian, and Spanish.
Highest Degree Obtained

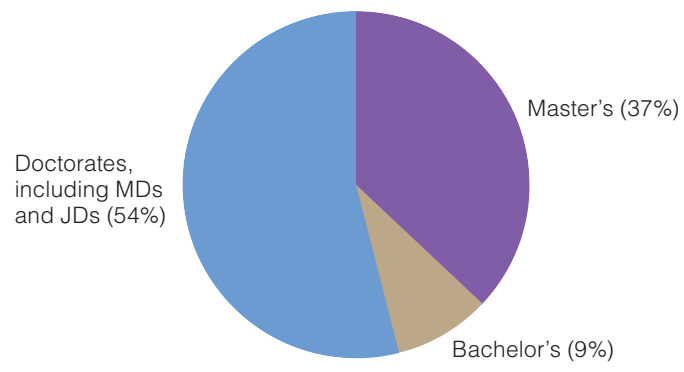

\section{Disciplines}

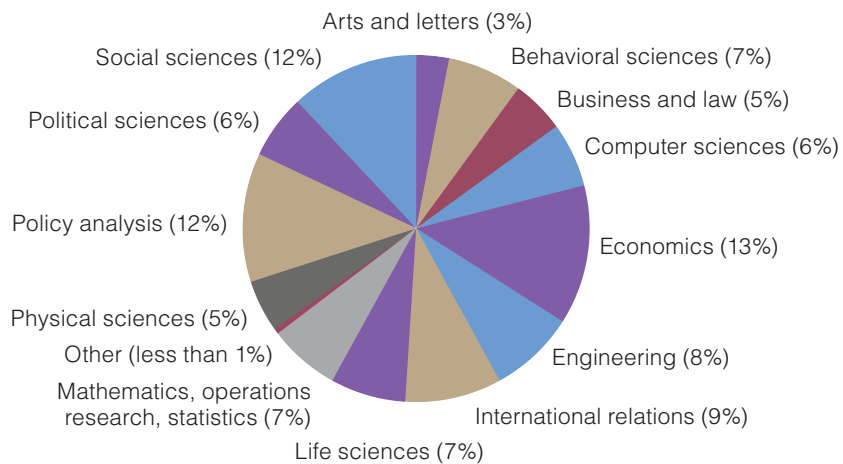


Publications

Last year, we added 490 RAND publications and more than 500 journal articles to our growing digital library -23,000 and counting-of reports, podcasts, videos, and commentary, which can be read or downloaded at www.rand.org.
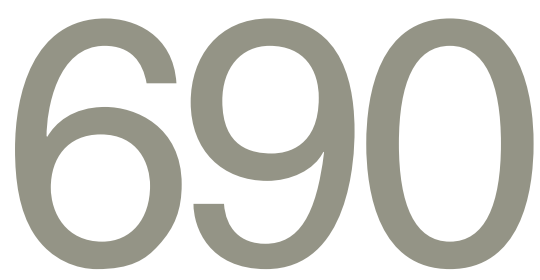

New Projects

Through more than

1,800 projects (including

almost 700 new ones),

RAND provides research

services, systematic analysis,

and innovative thinking to a

global clientele.

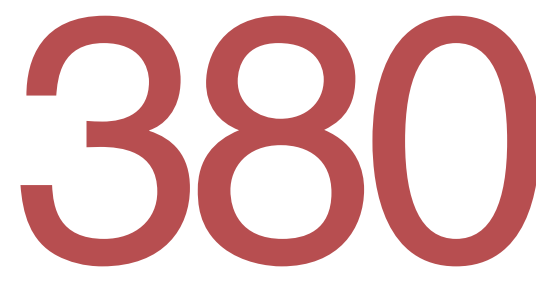

Clients and Grantors

We performed work for more than 380 clients and grantors, including government agencies, international organizations, and foundations.

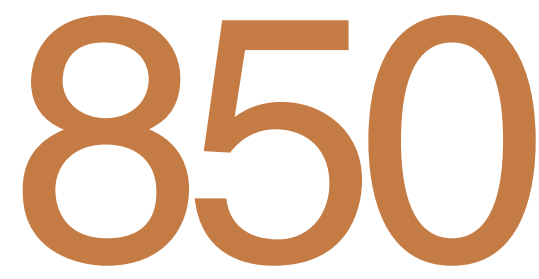

Donors

Gifts from donors help RAND deliver fact-based, actionable solutions grounded in rigorous analysis. They help fund our people, ideas, centers of excellence, and outreach.
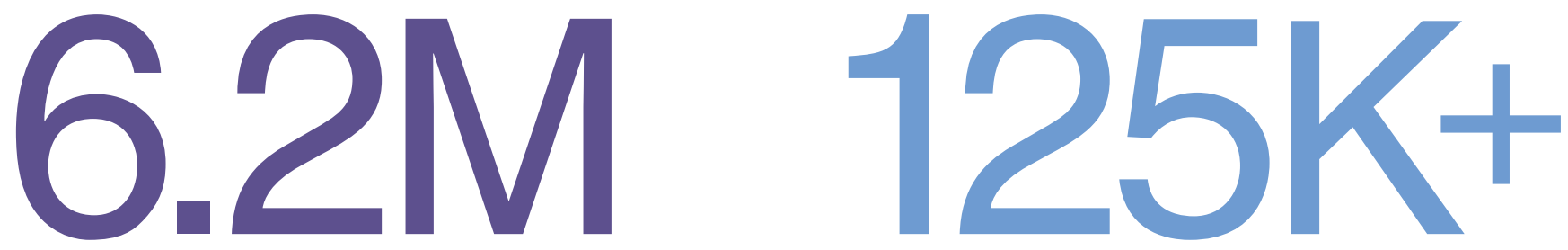

Web Downloads

Twitter Followers

To find out more about recent RAND Corporation research initiatives, events, and outreach activities, read our 2016 Annual

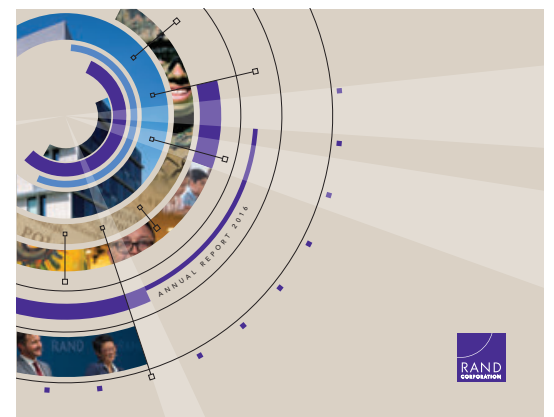

Report, available at

www.rand.org. 

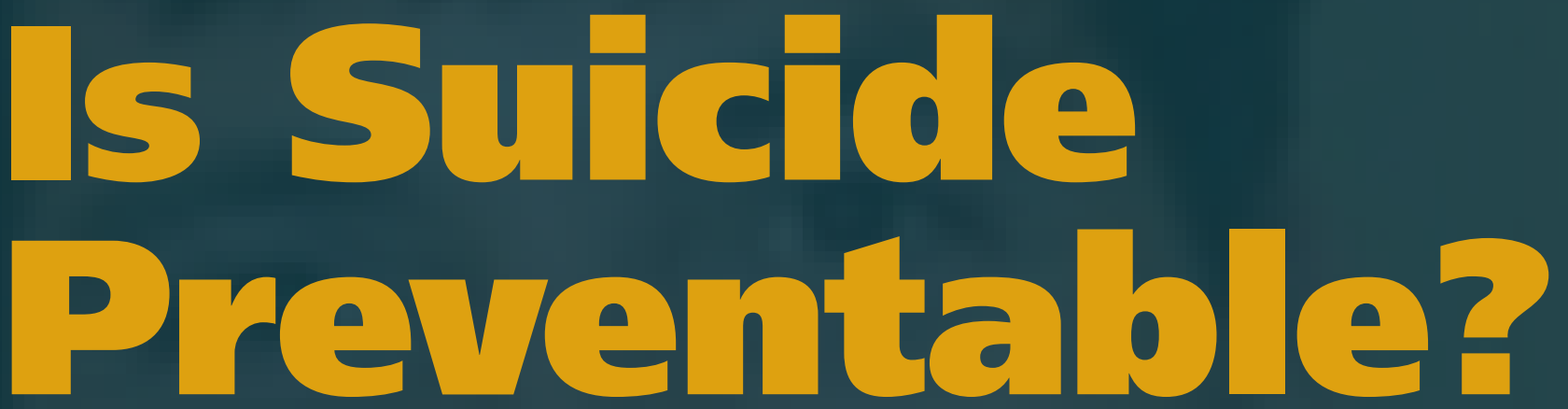

By Doug Irving, Staff Writer

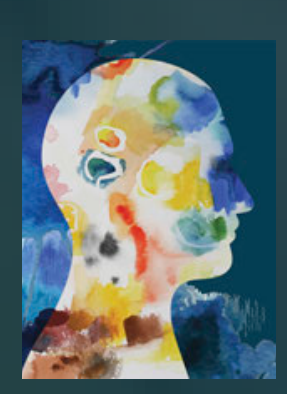

\section{In some circles, conventional wisdom about} suicide prevention suggests that one just needs to know what signs to look for. That's not the case. And suicide in the United States is on the

\section{rise. What's needed are some novel ideas, and more data to back up our assumptions.}

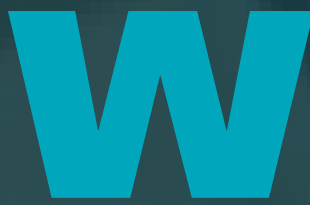

ilkins Kearney left a note for his wife on the kitchen counter, propped against their wedding picture. It began, "To dear Lilla," and ended, "I love you so much!" Then he pulled open a drawer and took out his gun.

His suicide seemed to come out of nowhere for his tight circle of friends and family. Looking back now, they remember no warnings, no signs of depression, nothing but the long, solitary runs he would sometimes take when work or life got him down. He was always just the same old Wilk, a loyal friend with a streak of mischief in his grin. "An active participant in life," one close friend said.

For years, public-service campaigns have stressed that suicide is preventable, that people can save a life if they just catch the warning signs early enough. But a recent RAND study found that the truth is much more complicated. In our search for answers, it concluded, we may have been looking in the wrong place.

"What did I miss?" Wilkins' widow, Lilla Wright Kearney, still asks herself. "I lived with him! What could I have changed? What could I have done? I would do anything to bring him back, and I can't, and it just breaks my heart." 


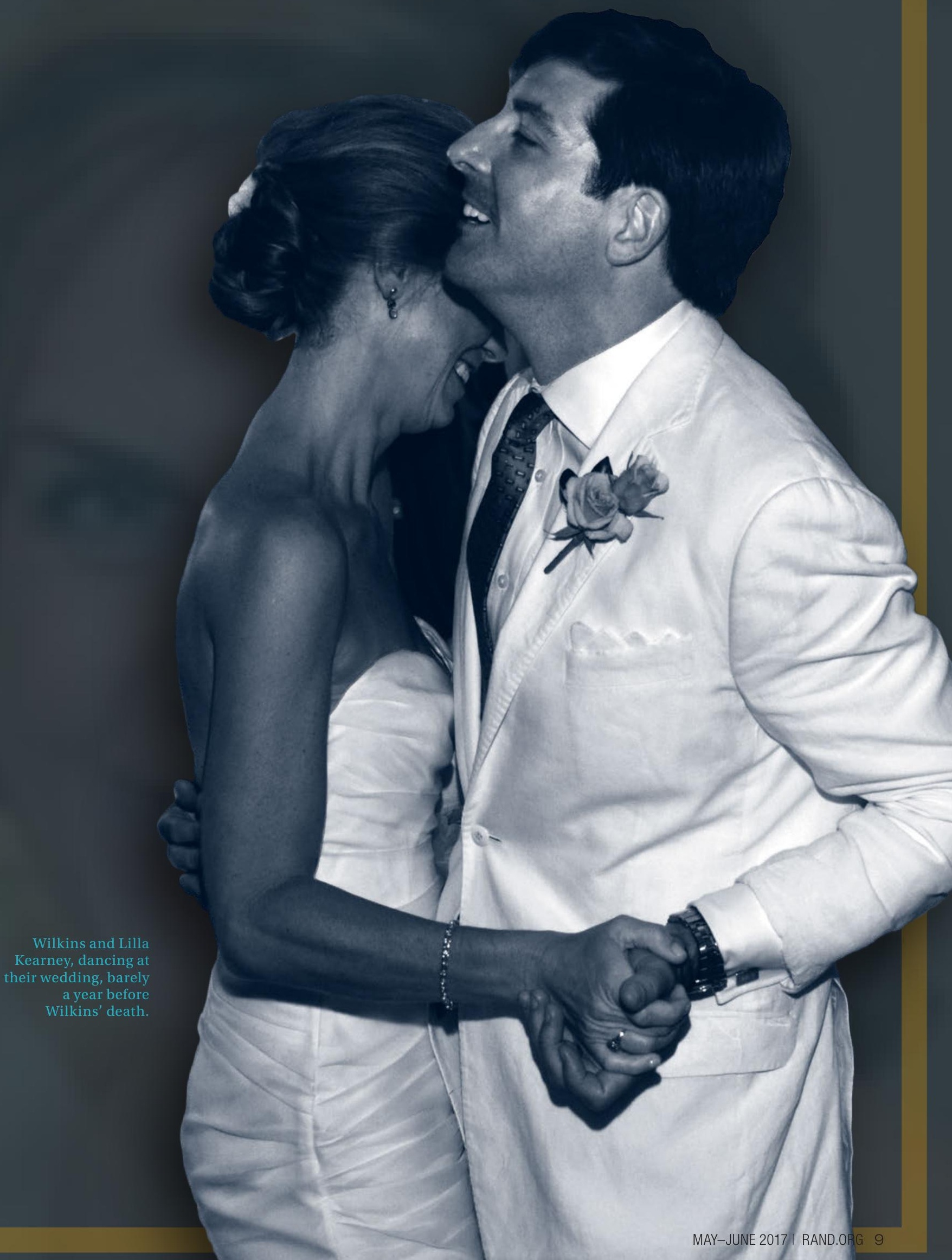




\section{The rate of suicide in the U.S. has dramatically increased}

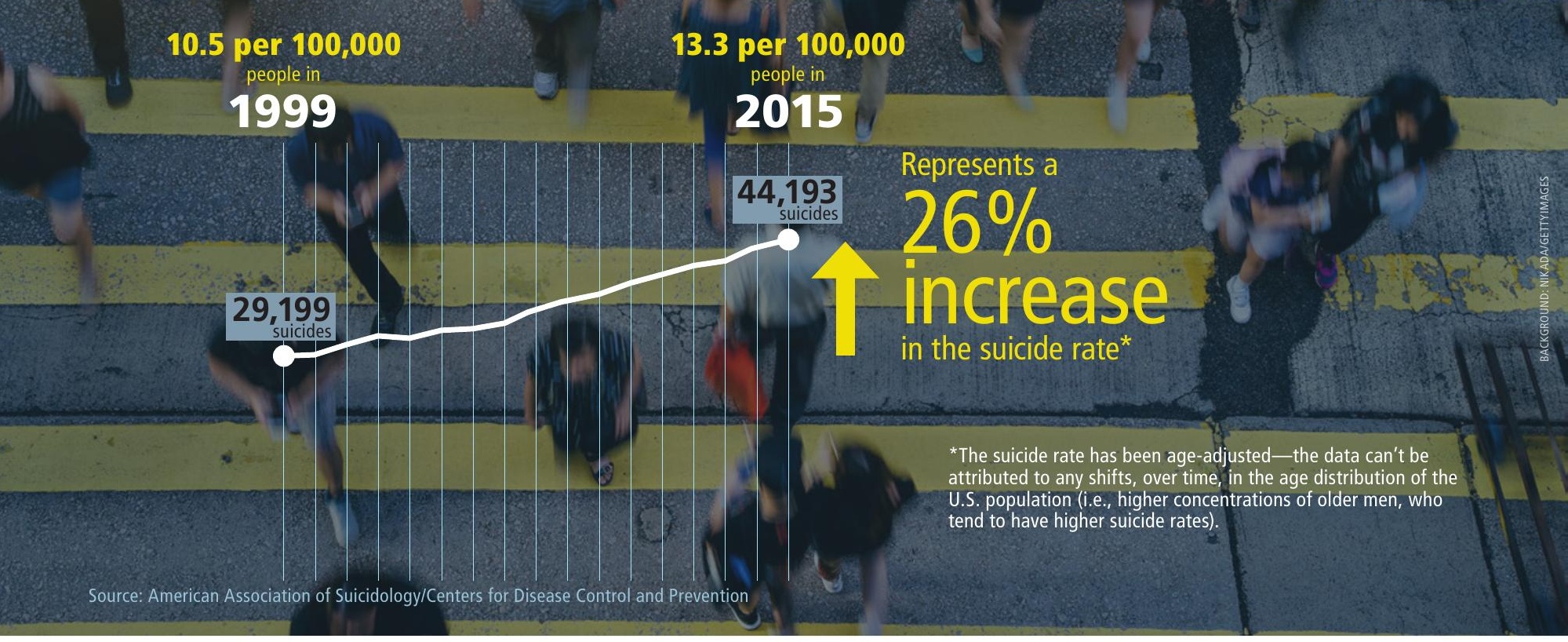

\section{Rising numbers}

Suicide has become one of the leading causes of death in America. The toll has risen, year after year after year, for more than a decade, especially among young women and middle-aged people. Around 121 people now die by suicide on an average day in America; on Halloween evening in 2016, Wilkins Kearney was one of them.

He was, by all accounts, a character-and in his hometown of New Orleans, that counts for something. He used to call into sports radio talk shows, introduce himself as Catfish from Grand Isle, and then hold forth on Saints football. He cracked up the congregation at his own wedding when he ended his vows with a long and loud, "A-MEN!"

That was just 14 months before his death.

"I've replayed my memories so many times," said one of his best friends, Todd Thompson. "Nobody had a clue. Here's somebody I've known since diapers, who's in that much pain, and nobody knew."

The idea that there should be telltale warning signs when someone is sliding into suicidal distress has been so well publicized that it's now accepted as fact. But the research is surprisingly thin. One study found dozens of different warning signs listed on prominent suicide-prevention websites, few with any published research backing them up, and many so vague they could apply to almost anyone at some point.

\section{A novel approach}

Rajeev Ramchand studies suicide as a senior behavioral scientist at RAND. His work has helped suicide hotlines better respond to callers in crisis, and helped military leaders better address suicide risks in the ranks. But he has always been troubled by that lack of hard evidence for the warning signs that have become a central part of suicide-prevention campaigns.

Starting in late 2015, he and a small team of researchers embedded themselves with the coroner's office in New Orleans, a partnership facilitated by the RAND Gulf States Policy Institute. They were there to study suicide up close, not in case files and medical summaries, but face to face with people who had lost loved ones, listening to their stories.

They interviewed the families of 17 people who had died by suicide, conducting what Ramchand describes as psychological autopsies. They asked about daily routines, relationships, health and financial problems, the presence of guns in the house or a note left behind. One clear pattern emerged: In almost none of the cases did the usual warning signs provide a reliable signal that a life was spiraling toward suicide.

That's not to say those warning signs weren't present. In fact, most of the people had withdrawn, become anxious or aimless, said they had no reason to live or even talked openly about suicide. The problem was that those were not new behaviors. 
More than two-thirds of the people in the study had a diagnosed mental illness; more than half were using illegal drugs. For their families, the warning signs were a daily fact of life, not a new red flag. "They did not necessarily think that their loved ones were not at risk for suicide," the researchers wrote, "but rather felt that suicide was a chronic risk."

In only four of the 17 cases did the researchers find warning signals that were truly new behaviors. But even then, it would have been hard to see them for what they were against a backdrop of distress or depression. Three of the people had recently been arrested or were under criminal investigation. The fourth had attempted suicide before and had just lost his job.

"We have to be careful about these warning signs and not create the false hope that people can just be vigilant for them," Ramchand said. "These are really way more complicated than they appear on their face."

The study was small, and Ramchand is quick to say more research is needed to either back up or back off the idea of warning signs. But its findings suggest a different approach to suicide might help more families and save more lives. "It shifts our focus," he said.

\section{Not to blame}

He still believes most suicides are preventable. But it requires digging deeper into depression, mental illness, and other known risk factors that don't fit so neatly on a public-service brochure. What is needed instead, he says, are high-quality programs for people with mental health problems, and support services for families struggling with depression. The time to intervene is not just in the hours or days before a suicide attempt, but in the months and even years leading up to it.

Ramchand sees one other important lesson in the study's findings, a message for the families and friends who have lost loved ones to suicide. "They are not to blame," he says. "They didn't miss anything."

That's still a daily hurt for the people who loved and lost Wilkins Kearney. They have teamed up with Ramchand on suicideprevention efforts in New Orleans, although Wilkins' case was not part of the RAND study. If it had been, his widow would have told the researchers that there were no signs he was in such pain. Just those few times when he said he didn't want to talk, and then disappeared on a long run.

She keeps a favorite picture of Wilkins near her kitchen sink, so that she can look at him every night while she makes dinner. "The smile on his face in that photo," she says, and then pauses. "Just the love. The love he had for his friends, the love he had for me. That's what I see. I don't see an unhappy person. I don't see the sadness. I just see that ginormous smile."

Wilkins was a man of traditions, and one of his favorites was the annual Mardi Gras party he organized with his friends. They kept it going this year as a fundraiser in his memory. It drew some 500 people, including Ramchand, and raised more than $\$ 50,000$ for mental health programs.

They called it Wilkapalooza, and they decorated t-shirts, hats, and belts with its logo: a giant catfish.

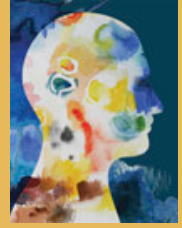

\section{RESEARCH IN THE PUBLIC INTEREST}

RAND Ventures is a vehicle for investing in policy solutions. Philanthropic contributions support our ability to take the long view, tackle tough and often-controversial topics, and share our findings in innovative and compelling ways. RAND's research findings and recommendations are based on data and evidence, and therefore do not necessarily reflect the policy preferences or interests of its clients, donors, or supporters.

Funding for this venture was provided by gifts from RAND supporters and income from operations.

\section{PUBLICATION}

"Opportunities to Intervene? 'Warning Signs' for Suicide in the Days Before Dying," by Rajeev Ramchand, Enchanté Franklin, Elizabeth Thornton, Sarah Deland, and Jeffrey Rouse, was published online in the journal Death Studies in January 2017. 
A FOCUS ON THE RESEARCH OF

Giacomo Persi Paoli, Michael McNerney,

and Sarah Grand-Clement

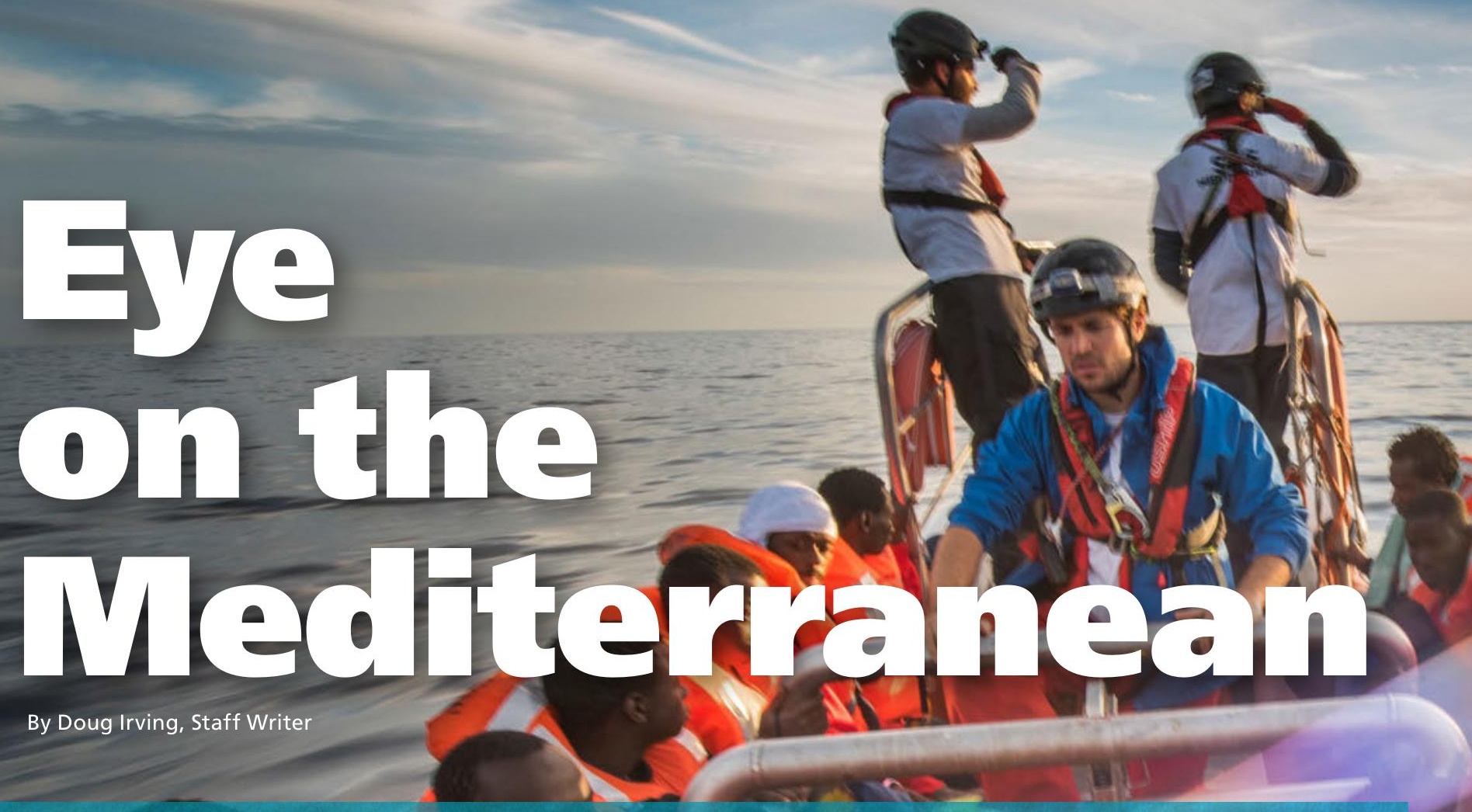

The countries bordering the Mediterranean Sea-from Algeria to Egypt in North Africa; from Israel to Syria in the Levant; and Turkey, Greece, and Italy in Europe - are facing unprecedented stress. A former lieutenant with the Italian Navy is now a RAND Europe researcher, working to help others appreciate the scope of the crisis in the Mediterranean. 


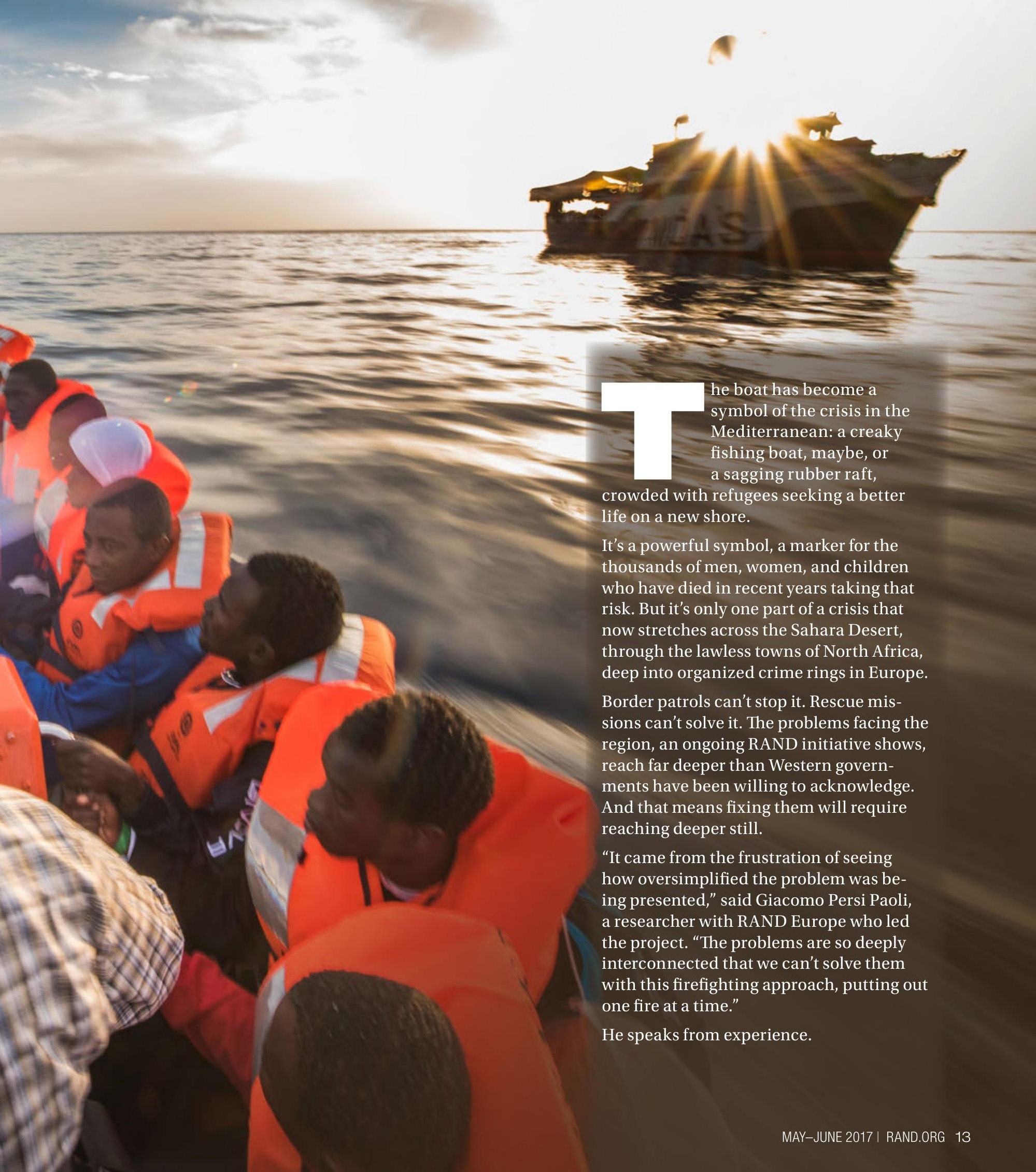




\section{A man with a mission}

It was dusk when the boat first appeared as a blip on the radar screen off the coast of Libya. On board the Italian naval frigate where Persi Paoli was a lieutenant, an emergency buzzer clanged as the captain ordered all hands on deck.

Persi Paoli could see hundreds of arms waving and reaching for help as the old wooden fishing boat came into view, rolling on the waves. He and his shipmates saved
Giacomo Persi Paoli served as a lieutenant aboard the ITS Scirocco. During Persi Paoli's time in service, the Italian naval frigate performed rescue operations in the Mediterranean Sea.

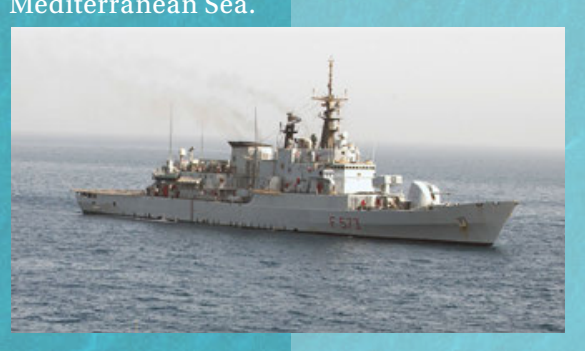
400 lives that night, the first of what would be half a dozen rescue missions in which he participated. He remembers just hoping the little boat would stay afloat long enough as the waves pounded against its ragged hull.

"You could really tell that without you, these people wouldn't have seen the light of the next day," he says now. "We were desperately looking for these people, because we knew they were out therewomen, kids-and they needed help."

More than 5,000 people died trying to cross the Mediterranean last year, the deadliest on record. They came from the shelled neighborhoods of Syria, the desperate villages of Eritrea and Gambia. Somalia lost so many people to the sea that a warning began to make the rounds of Twitter there: \#DhimashoHaGadan, or "Don't Buy Death."

That's what people see on the nightly news: the bodies washed ashore, the crowded migrant camps, the boats. But Persi Paoli, who left the Italian Navy in late 2013 and joined RAND as a research leader specializing in national security, wanted to widen the lens. He called the project the Mediterranean Foresight Forum.

\section{Follow the money}

The researchers traced the roots of the crisis back to the shattered promise of the Arab Spring and the cratered cities of Syria and Libya, but also to European capitals too divided to act. They mapped the smuggling routes that now crisscross Africa and the Middle East, and then followed the money-billions of dollars every year-to criminal networks flourishing in North Africa and Southern Europe.

They showed that what may have once been many individual threats to the stability of the region have now merged, creating a cycle of un- rest that feeds back on itself. In Libya alone, for example, the same black markets that provide fake passports and flimsy boats to migrants can also deliver hashish to European drug dealers and shoulder-fired missiles to Syrian fighters.

The grinding poverty of West Africa, the unrest of North Africa, and the terrorist threat of ISIS can no longer be treated as unrelated challenges, the researchers concluded. Those problems now all seem "to literally spill into the Mediterranean Sea," they wrote, threatening the security and stability of the two continents that share its shores. The future of Europe has become inextricably linked by sea to the future of the Middle East and North Africa.

"All of these pieces get reported on, but nobody really weaves them together," says Michael McNerney, a senior researcher at RAND, where he serves as associate director of the International Security and Defense Policy Center. "We need to look at the big picture, because if these problems continue to destabilize Europe and the region, that could be devastating for U.S. interests."

"The crisis is getting worse," he added. "But there is no one stepping up, offering resources or saying, 'We need to radically reconsider what we're doing."'

\section{The immediate need fora (1) Ing-term strategy}

The United States, Europe, and NATO need to begin sharing intelligence in a way they have not managed since the migrant crisis began. They need to put more ships into the Mediterranean, more security agents at the border. But they also need to take an active role-through trade deals, for example-in stabilizing countries like Tunisia before they get pulled into the exodus.

The response from Europe and the United States has so far been too little, and too late. "What should have been rapid, robust engagement has often been more of a cautious voyage of discovery," the researchers wrote in one of a series of recent reports. They suggested a "diplomatic surge" as a practical first step, to bring the nations of Europe, the United States, and NATO together to hammer out a single, unified strategy to address the crisis.

From across the Atlantic, the security and stability of the Mediterranean region might seem like a European problem, they noted. But what happens there-from Syria to Egypt to the beaches of Libya-has a direct impact on the 


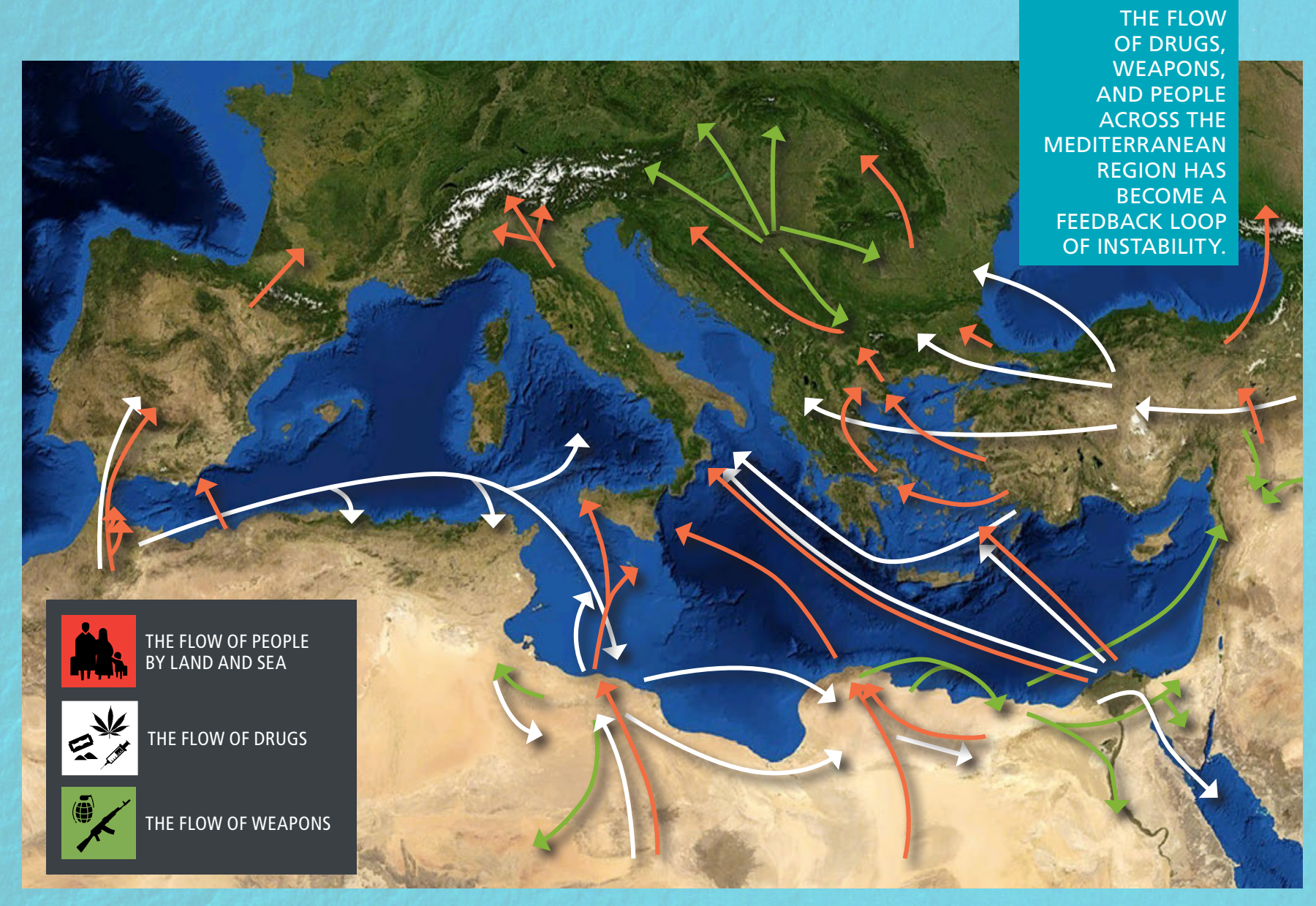

security and interests of the United States. That should add some urgency to Department of Defense planning.

"The scale of the problem is unprecedented," Persi Paoli said. "You can't think of solving it just by managing the immediate crisis. It's long term. But if you don't start doing something, you won't get any closer. In ten years, we'll still be talking about the need for a long-term strategy."

\section{In search of saf fety and stability}

It's been a few years since he was out there, scanning the horizon for the next boat. The enormity of what he saw still comes to him in unexpected moments: the people reaching from the water, the refugees huddled on deck. It was a reminder, as he worked on the Mediterranean Foresight Forum, of the stakes involved: not just the safety and stability of two continents, but the lives of hundreds of thousands of people who have made the journey, and thousands more who have yet to start.

"When my daughter was born and I held her in my arms, that's when it really hit me," he said. "There were pregnant women on those boats that we rescued. There were small children. They were people that, because of us, at least had a chance.

"Somewhere in North Africa or Syria, there are parents who are having to go through that, just to give their children that chance."

\section{RESEARCH IN THE PUBLIC INTEREST}

Funding for these RAND Ventures was made possible by the independent research and development provisions of RAND's contracts for the operation of its U.S.

Department of Defense federally funded research and development centers.

For more information on the Mediterranean Foresight Forum project, visit www.randeurope.org/mff.

\section{PUBLICATIONS}

Against the Rising Tide: An Overview of the Growing Criminalization of the Mediterranean Basin www.rand.org/t/PE220

Troubled Waters: A Snapshot of Security Challenges in the Mediterranean Region www.rand.org/t/PE221

Cross-Cutting Challenges and Their Implications for the Mediterranean Region www.rand.org/t/PE222

Regional Foreign Policy Dynamics and Their Implications for the Mediterranean Region www.rand.org/t/PE223 
This is a real

moment for

RAND, when

our policy

analysis can

play a major

role in helping

people in the

region.
Dalia Dassa Kaye directs the RAND Center for Middle

East Public Policy. Its goal: to inform policy in ways that help improve the security and well-being of people living in the region. Recent reports have focused on hot

topics from the Syrian civil war and the Iran nuclear deal to less-covered (but vitally important) crises such as the educational shortfalls faced by refugee children.
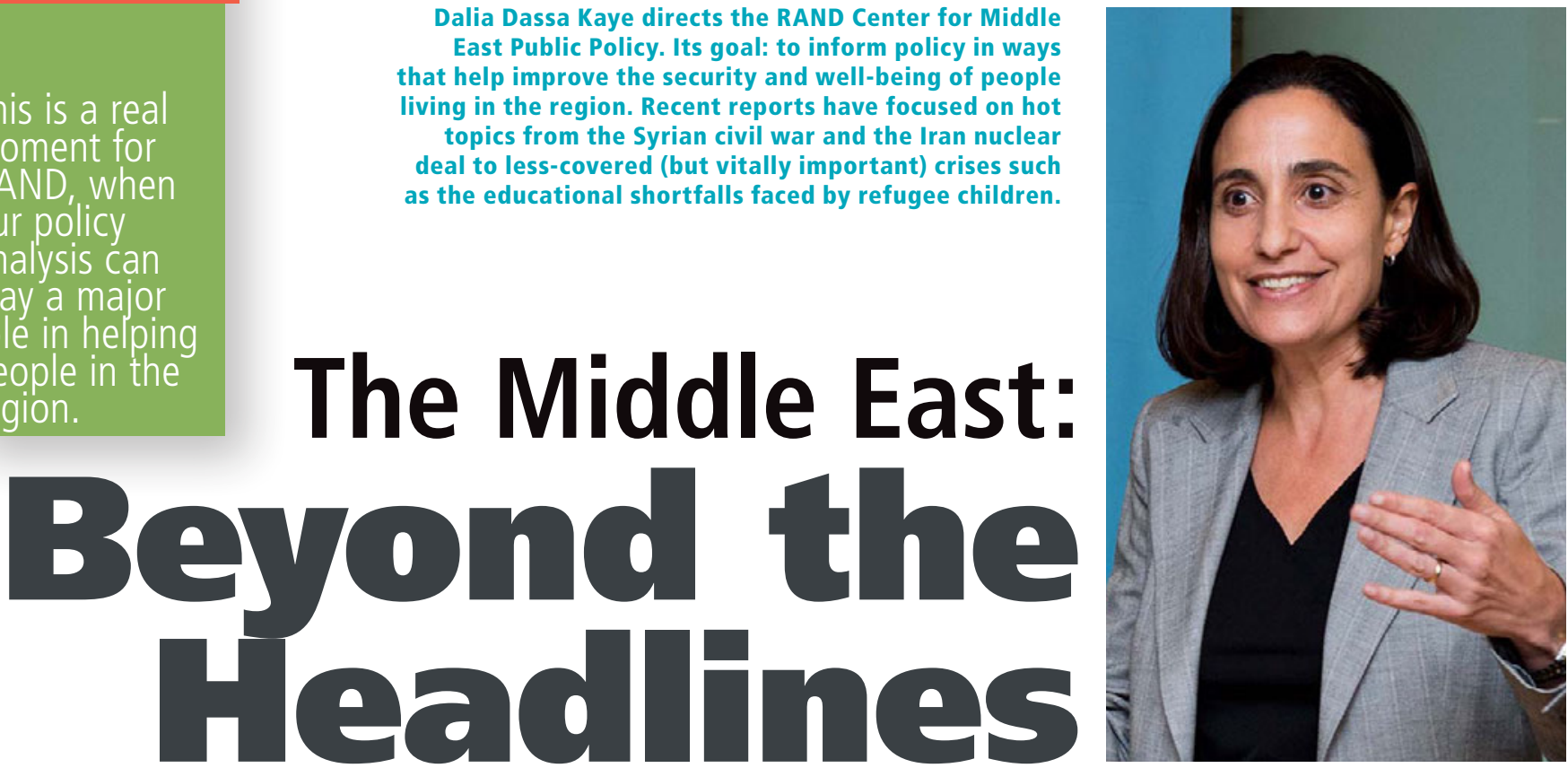

Q What are the major Middle East storylines you anticipate over the next few years?

A The daily headlines are terrorism and ISIS. But the day-to-day worries of people in the region are education for their children, failing health care systems, access to water, good jobs for young people, government accountabilitymatters that do not always make the headlines. But those are the big issues that are going to really shape the region's future. And the more that countries fail to address those domestic demands, the more vacuums that exist for extremists to exploit.

The other big storyline is the ongoing friction between the Iranians and the Saudis, and I would add Turkey into the mix now, too. This is not a dynamic that will resolve any time soon. And unfortunately, the unstable situation that you see in so many places-particularly Syria, but also Yemen and Iraq - will continue to be difficult arenas where this conflict plays out, with dangerous spillover across the region and beyond.
Those two big storylines are going to clash at some point. The question will be, Can these states continue with these regional power plays, and at the same time respond to their own domestic pressures? When is that going to give?

\section{What is RAND's role here?}

Most of these countrieseven the oil-rich countriesunderstand the need to diversify; they can't live on oil forever. They need to reform their education systems. They need to improve their infrastructure. Basically, they need to improve their societies, improve the well-being of their citizens.

Our work for the Kurdistan Regional Government is a good example of what we bring to the table. We worked on education, health, and unemployment issues there. We have a very good bench of experts who know the region well, speak fluent Arabic and other languages - and we can combine them with our survey analysts, our methodologists, all of our technical experts, to really assist these countries in major transformations that are underway.

We also give guidance to U.S. policymakers on how to bring more stability to this region and de-escalate these conflicts. RAND published a peace plan for Syria that I think is a good example of that. That's the best thing we can do: Create an environment of de-escalation so that we can then directly work on these very important socioeconomic challenges.

\section{What drove RAND's recent decision to launch an} Arabic-language website?

There's been a real dearth of objective analysis in the region, so RAND is really filling a need. There is a hunger for it, as demonstrated by the many thousands of downloads of translated RAND studies over a short time.

The site also helps explain to decisionmakers in the region who we are. We're not some mysterious force in U.S. policy; we're a transparent and open organization that makes our research and analysis available for free. It's about the public good.
What are some recent projects that spotlight the center's work in the region?

Philanthropic contributions have really allowed us to do innovative research on issues that might not otherwise be funded. We're looking at the regional impact of the water crisis in Gaza; at food security; at Iran after the nuclear deal; at the costs of the IsraeliPalestinian conflict; at regional displacement; at emerging relations between China and Israel; and at Russia's role in the region. We're currently trying to raise support for a new RAND Israel program.

This is a real moment for RAND, when our policy analysis can play a major role in helping people in the region. We see that in the Israeli-Palestinian arena, in Jordan, in Tunisia, in Lebanon, and in the Arab Gulf. Those are all places where we think we can have an impact, where we hope we can make a difference. $\boldsymbol{P}$ 


\section{By Ty
NuMS
Bars}

900,000

Approximate number of Syrian refugee children who are not attending school. Researchers who traveled through the region for a 2015 report found that school systems in Turkey, Lebanon, and Jordan were not prepared to accommodate long-term influxes of refugee children. The international community needs to make that more of a priority, they wrote, because it may be years before Syrians can return home.

MORE AT www.rand.org/t/RR859

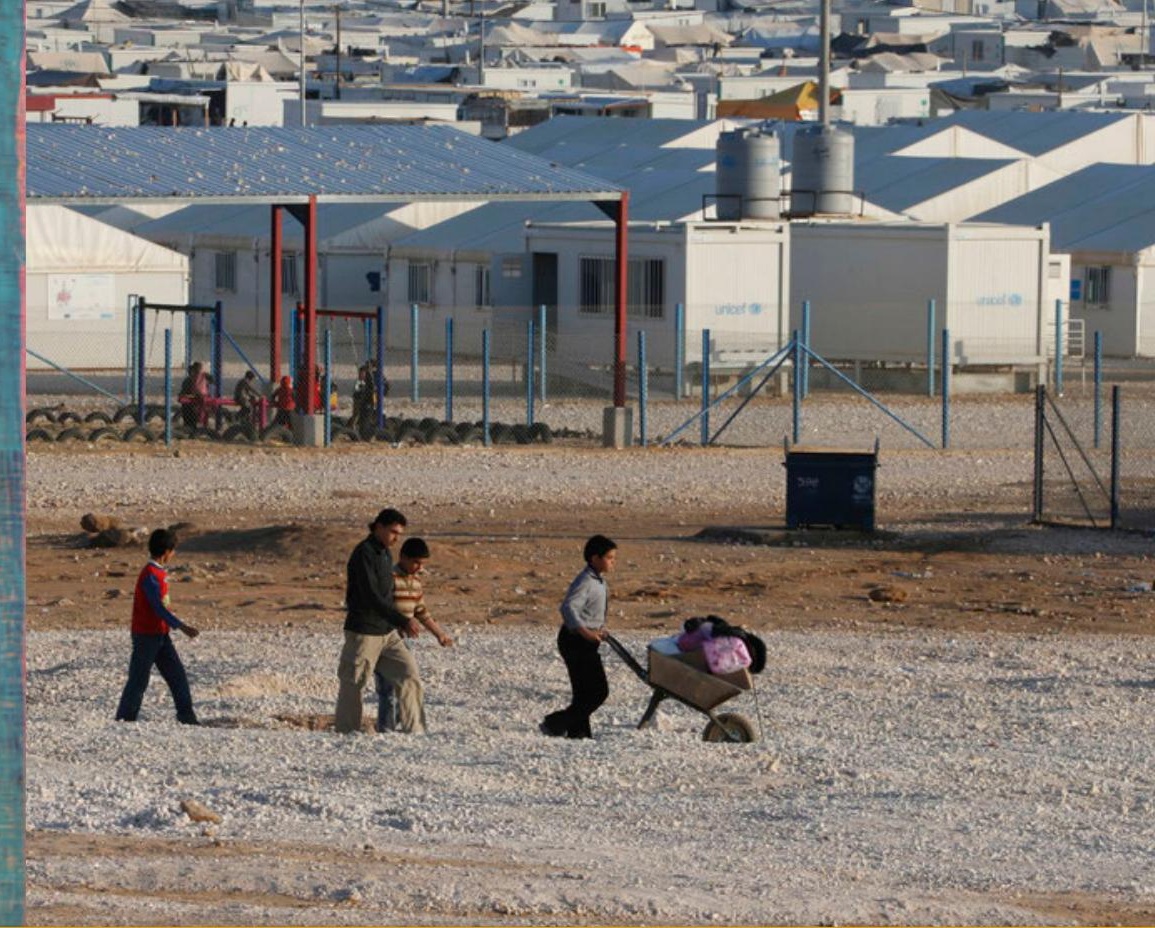

35,599 Active component

256,831 National Guard and Reserve

1,098,839 Dependents

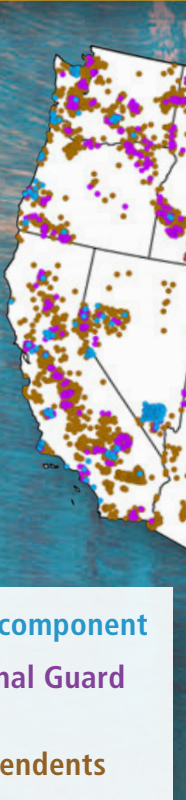

\section{2...}

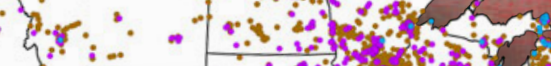

i.

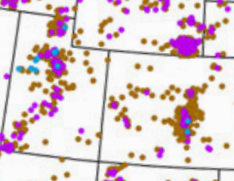
कis fion

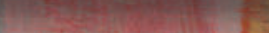

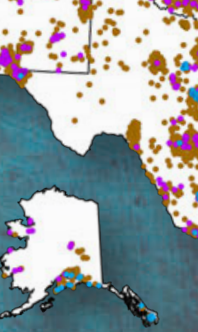




\section{RAND LAUNCHES}

\section{Arabic-Language Website}

A new Arabic-language website, designed to bring RAND research and analysis to the Arabic-speaking world, is available online at www.rand.org/ar. The site will include more than 200 RAND reports translated into Arabic over the coming years - reports determined to be of most interest to the Arabic-speaking world, as well as those focused on issues in the Middle East. Topics will include education policy, international affairs, health care, and regional governance.

The goal of the project is to share the findings of RAND research and analysis with key policymakers and the general public in the Middle East. RAND's research and analysis will help leaders in the region make more-informed decisions around key areas that affect citizens.

RAND has long made reports and other research products available for free download on rand.org. With this project, we offer Arabic-speaking policymakers and citizens access to RAND research and analysis in their own language.

The translation project is an initiative of the RAND Center for Middle East Public Policy.
With this

project, we offer

Arabic-speaking

policymakers and

citizens access to

RAND research

and analysis

in their own

language.

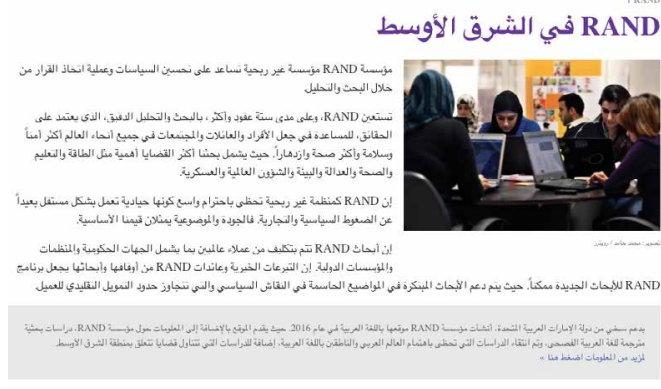

\section{RAND CHOSEN TO OPERATE THE}

\section{Homeland Security Operational Analysis Center}

The U.S. Department of Homeland Security selected RAND to operate the Homeland Security Operational Analysis Center.

The center will conduct analyses and make recommendations to strengthen the Department of Homeland Security across its missions to prevent terrorism and enhance security, secure and manage U.S. borders, enforce and administer immigration laws, safeguard and secure cyberspace, and strengthen national preparedness and resiliency.

The new center - a federally funded research and development center (FFRDC) - is expected to focus on seven areas: acquisition studies, homeland security threat and opportunity studies, organizational studies, regulatory doctrine and policy studies, operational studies, research and development studies, and innovation and technology acceleration.

The inaugural director of the center is Terrence K. Kelly, a senior operations researcher at RAND; Henry $\mathrm{H}$. Willis, a senior policy researcher, serves as associate director. 

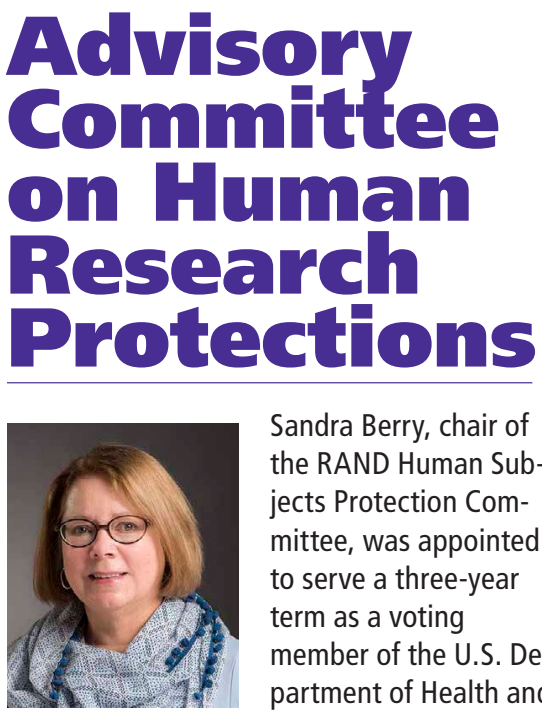

Sandra Berry, chair of the RAND Human Subjects Protection Committee, was appointed to serve a three-year term as a voting member of the U.S. Department of Health and Human Services (DHHS) Secretary's Advisory Committee on Human Research Protections.

The 11-member committee provides expert advice to the DHHS Secretary through the Assistant Secretary for Health on topics related to the protection of human research subjects, as well as recommendations to improve the quality of the system of human research protection programs.

The committee focuses on such issues as the treatment of special populations, including children, prisoners, and the decisionally impaired; pregnant women, embryos, and fetuses; international populations; the identifiability of research subjects; and investigator conflicts of interest.

The DHHS Secretary is responsible for regulatory oversight of the system for protecting human subjects in biomedical and behavioral research supported or conducted by DHHS. This responsibility extends to organizations that conduct such research, the Office of Human Research Protections, and other DHHS entities.

The committee holds at least two public meetings per year and includes nonvoting ex-officio members from the Centers for Disease Control and Prevention, the Food and Drug Administration, the National Institutes of Health, the Indian Health Service, and other DHHS organizations, as well as from a range of other U.S. government departments, including the U.S. Department of Defense, U.S. Department of Education, U.S. Department of Veterans Affairs, and the National Science Foundation.

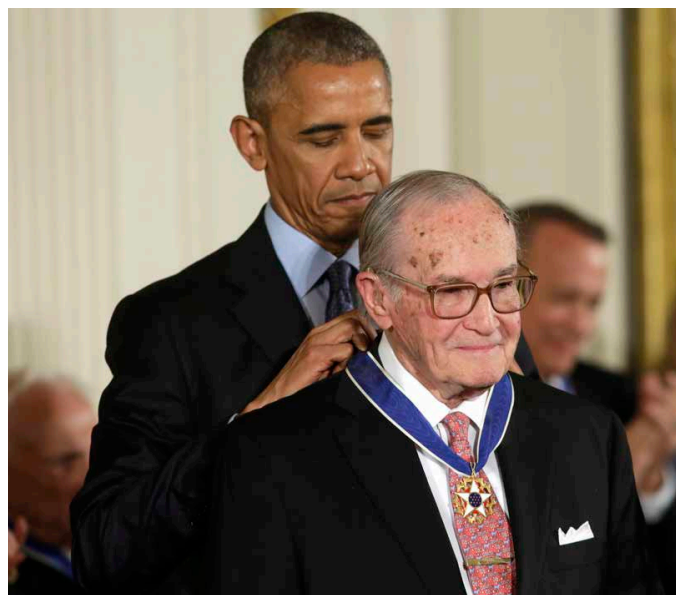

\section{FORMER RAND TRUSTEE} MINOW RECEIVES

\section{Presidential Medal of Freedom}

Former RAND trustee Newton ("Newt") Minow was awarded the Presidential Medal of Freedom, the nation's highest civilian honor. President Barack Obama presented Minow with the award at a ceremony at the White House on November 22, 2016, where he joined this year's 20 other distinguished honorees, including Bill and Melinda Gates, Frank Gehry, Maya Lin, and Robert Redford.

Minow, an attorney with a long and distinguished career in public life, served as a RAND trustee from 1965 to 1997, including a term as chairman of the board. During his time as chairman, he encouraged RAND to establish one of the original eight graduate schools of public policy-now the Pardee RAND Graduate School.

After serving in the U.S. Army during World War II, Minow served as a Supreme Court clerk and counsel to the Governor of Illinois. In 1961, President John F. Kennedy selected Minow, then 34, to serve as Chairman of the Federal Communications Committee (FCC), where he helped shape the future of American television and was a vigorous advocate for broadcasting that promoted the public interest.

In the five decades since leaving the FCC, Minow has maintained a prominent private law practice while devoting himself to numerous public and charitable causes.

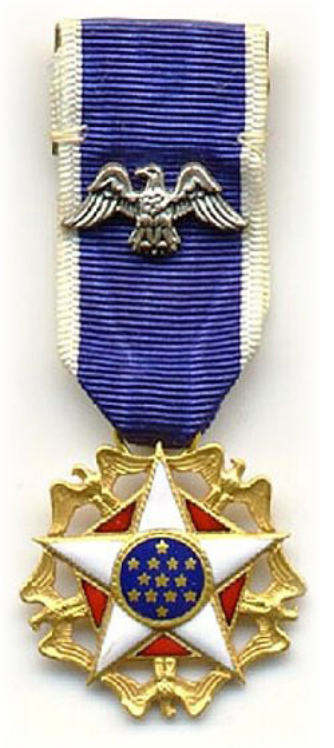




\section{Alexander and Elizabeth Kendall stayed up late on the nights after the 2016 election, talking about the future. They were young parents, academics at heart, and what they saw was a country moving away from discourse and deliberation in favor of win-at-all-costs politics on all sides.}

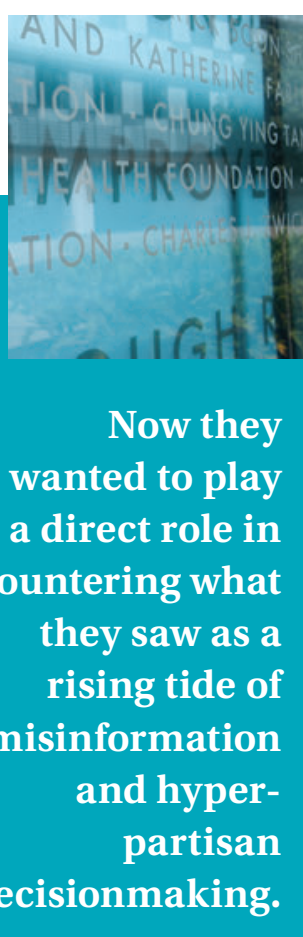

decisionmaking.
II 'alternative facts' is a term?" Elizabeth would ask later. "Let's take a step back. Who's going to cut through the nonsense?"

The answer, they decided, was RAND.

The Kendalls recently joined the RAND Policy Circle, a community of donors whose support allows RAND to pursue objective, nonpartisan answers to some of the most difficult questions that America and the world are facing. They wanted to make a difference, they explained, and saw their support of RAND as an investment in the search for facts over factions.

"It felt like one thing we could do as a family," Alexander said. The tone of the election drove home the need for careful analysis, reasoned decisions-disagreements over policies and proposals, perhaps, but not over basic facts. "Apparently, that's up for debate," Alexander said.

The Kendalls knew of RAND as a research organization with a reputation for rigor; they live in Santa Monica, not far from RAND's headquarters campus. She's 34 years old, an attorney by training. He's 35, a private investor with a distant connection to RAND: A relative worked in the computer sciences department in the 1960s. It was his idea to call RAND as they sat up one of those nights after the election, talking about what they could do. They had been generous in their philanthropy before, mostly on behalf of schools they had attended. Now they wanted to play a direct role in countering what they saw as a rising tide of misinformation and hyperpartisan decisionmaking.
"We wanted to make sure that policy is being made with facts, with reason, regardless of topic," Elizabeth said. "How can we contribute to these principles that are so important to us?"

That question has taken on new urgency at RAND. President Michael Rich has pushed back in recent months against what he describes as a national epidemic of "truth decay." Polarization inflamed by truth decay, he has said, is the gravest threat facing America: "When everyone has their own facts, then nobody really has any facts at all."

The Kendalls have taken up that challenge, beyond their financial support. They have made it a point to go to RAND events and talks that are open to them as Policy Circle members. Elizabeth recently attended a lunch hosted by Brian Michael Jenkins, senior adviser to the president at RAND and an international authority on terrorism.

"I'll come home from these events and it's like, 'Elizabeth, I have to tell you all about...' whatever topic they were discussing," Alexander said.

That's what the public discourse in America needs more of, they said. They describe their support of RAND as a vote for more independent research, more analysis, more good, hard facts in the hands of people making decisionsand the people who elect them.

"When there's so much misinformation out there," Elizabeth said, "we need information from a trusted source like RAND." 
It took President

Reagan seeing the

movie for Ware's

warning to be taken

seriously. Reagan asked

his advisers if life

could imitate art in this

case, and he was soon

assured that it could.
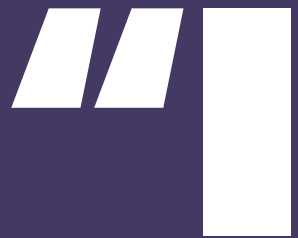

$s$ this a game or is it real?"

It's a question the main character asked in the 1983 film WarGames

26 February, 1981

Dr. Willis Ware

7700 Main Street

santa Monica,

Dear Willis:

Here is the latest version.

universal computer expert's proble

Also enclosed is the Universat please let

she sees then. read them.

she after you

warm regards ,
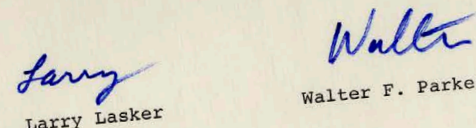

Larry Lasker

Walter E. Farkes

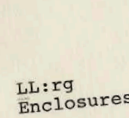

Enclosure
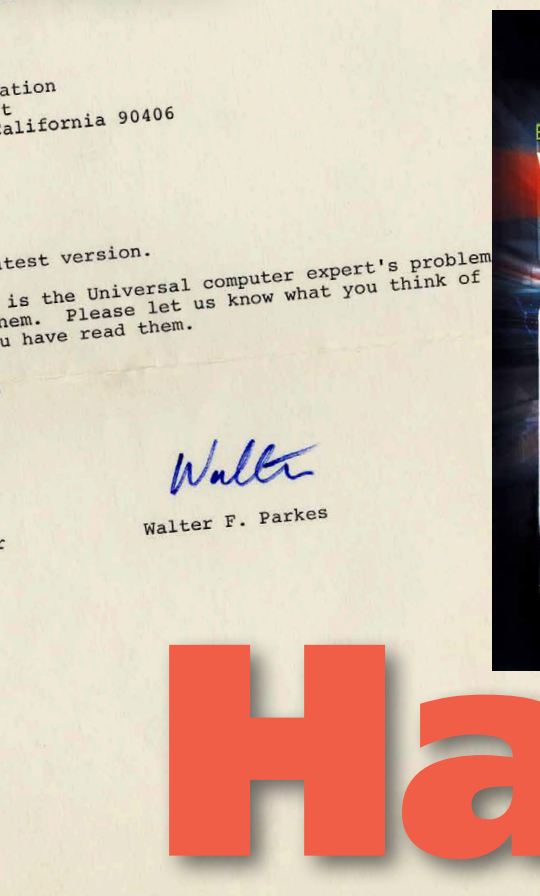

$-1.5$.

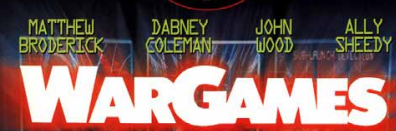

Ai CAM $=$

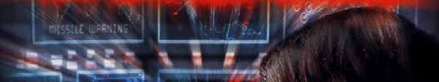

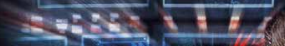

what you think

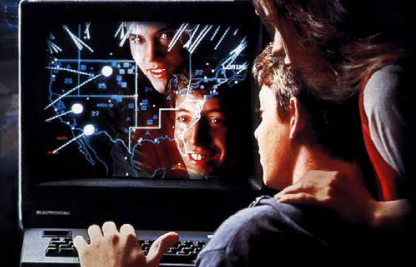

-

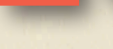

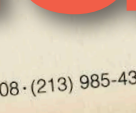

CTYPLAZA. UNI RSAL CITY, CA $91608 \cdot$ (213) 985-4321
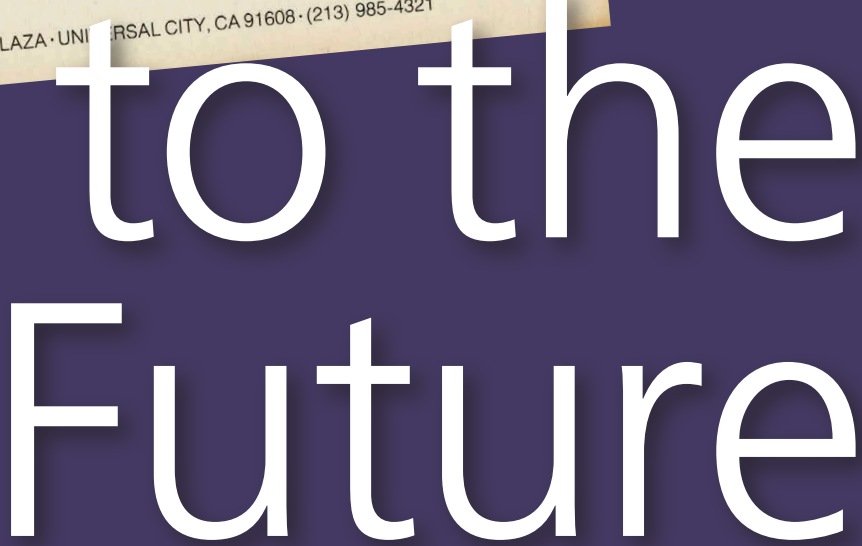

RAND Helped War Games Writers Delve into "Demon Dialing" after he mistakenly hacked into a defense system instead of a video game and nearly started a nuclear war with the Soviets. "Is it real?" is the question the filmmakers asked RAND as they researched whether their premise was possible.

RAND's Willis Ware had already answered whether the nation's defense systems were secure in 1967 as the U.S. military was developing the ARPANET-a precursor of the Internet based on RAND's packetswitching technology. Ware, who had helped develop some of the ARPANET technology, warned that the network could be vulnerable.

Fast-forward about 15 years, and screenwriters Lawrence Lasker and Walter Parkes were doing research for WarGames. They had heard about "demon dialing" — an autodialing technique for hacking into networkswhich was the premise for the film.

Lasker lived a few blocks from RAND, and the writers decided to ask if researchers could verify that the North American Aerospace Defense Command (NORAD) could be hacked. Ware told them that NORAD could indeed be infiltrated if someone dialed the right number. The writers ran with it.

It took President Reagan seeing the movie for Ware's warning to be taken seriously. Reagan asked his advisers if life could imitate art in this case, and he was soon assured that it could. In 1984, National Security Decision Directive 145 was put in place, marking the first national policy on reducing the vulnerability of computers.

Sources: The New York Times, RAND archives 


\section{HEADQUARTERS CAMPUS}

1776 MAIN STREET, P.O. BOX 2138

SANTA MONICA, CA 90407-2138

\section{OFFICES}

SANTA MONICA, CA

WASHINGTON, DC

PITTSBURGH, PA

NEW ORLEANS, LA

BOSTON, MA

SAN FRANCISCO, CA

CAMBRIDGE, UK

BRUSSELS, BE

\section{CANBERRA, AU}

\section{Enjoy}

\section{RAND REVIEW}

on your tablet

or phone

NOW AVAILABLE FOR

BOTH Android \&iOS

\section{The free RAND REVIEW app} includes all the content of

the print edition-and more.
SAMSUNG • •

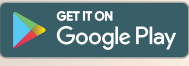

Download on the
App Store 